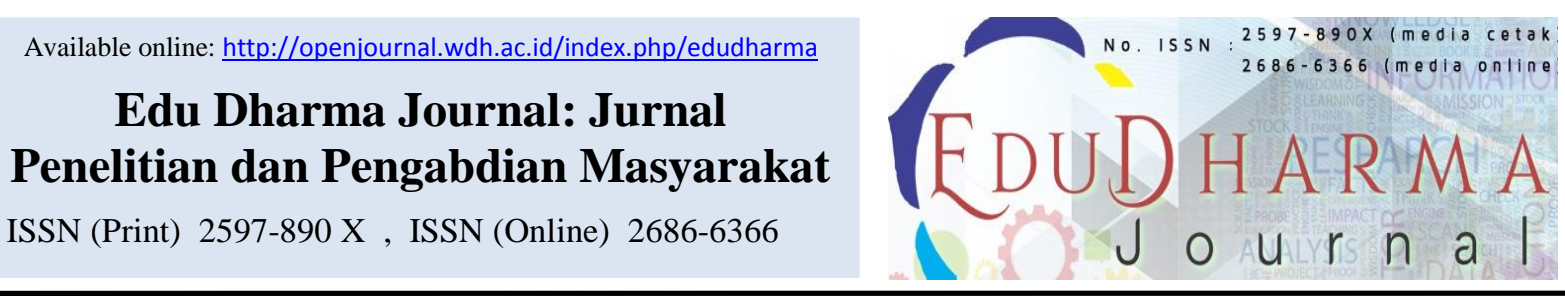

\title{
KAJIAN MANAJEMEN PENGELOLAAN LIMBAH PADAT MEDIS DI KLINIK INTI MEDIKA INSANI TANGERANG
}

\author{
${ }^{* 1}$ Tri Okta Ratnaningtyas, ${ }^{2}$ Fenita Purnama Sari Indah, ${ }^{3}$ Nurwulan Adi Ismaya, ${ }^{4}$ Nurkhikmah \\ Alwiyati
}

STIKes Widya Dharma Husada, Jalan Pajajaran No.1, Tangerang Selatan (15417), Indonesia

\begin{tabular}{|c|c|}
\hline ARTICLE INFORMATION & $A \quad B S S T R A C T$ \\
\hline $\begin{array}{l}\text { *Corresponding Author } \\
\text { Name : Tri Okta Ratnaningtyas } \\
\text { E-mail: triokta@ masda.ac.id }\end{array}$ & $\begin{array}{l}\text { Medical waste carries a greater risk to health. Such as diarrhea, } \\
\text { skin infections, dengue fever until hepatitis A, B, and C. Poor } \\
\text { handling of waste will also pose a risk of nosocomial infection. } \\
\text { To realize the quality of environmental health, it is necessary to } \\
\text { set standards for environmental health quality standards and }\end{array}$ \\
\hline $\begin{array}{l}\text { Keywords: } \\
\text { Clinic_1 } \\
\text { Health } \text { care_2 } \\
\text { Medical } \text { waste_3 } \\
\text { Management_4 }\end{array}$ & $\begin{array}{l}\text { implementing waste reduction. The health facilities had } \\
\text { produced more than } 296.86 \text { tons of medical waste every day. } \\
\text { Only about } 43 \% \text { of health service facilities that carry out } \\
\text { medical waste management have met the standards. Objective: } \\
\text { To examine the management of medical solid waste management } \\
\text { in Inti Medika Insani Clinic, Tangerang. Methods: This research } \\
\text { is a type of descriptive qualitative research. The object of this } \\
\text { research is the director of Inti Medika Insani Clinic, manager of } \\
\text { Inti Medika Insani Clinic, nurses, staff in charge of waste, } \\
\text { cleanig service. This research uses in-depth observation and } \\
\text { interview methods. Data collection techniques in this study is use } \\
\text { interview techniques conducted by telephone. Based on the } \\
\text { results of the study, Inti Medika Insani Clinic had not yet carried } \\
\text { out appropriate waste management. Klinik Inti Medika Insani } \\
\text { did not have sanitation workers, there were no available } \\
\text { budgets, facilities and infrastructure that were not yet maximal, } \\
\text { and there was no policy, monitoring and supervision. }\end{array}$ \\
\hline $\begin{array}{l}\text { Kata Kunci: } \\
\text { Klinik_1 } \\
\text { Pelayanan kesehatan_2 } \\
\text { Limbah medis_3 } \\
\text { Manajemen_4 }\end{array}$ & $\begin{array}{l}\text { A B S T R A K } \\
\text { Limbah medis membawa resiko yang lebih besar terhadap } \\
\text { kesehatan. Seperti diare, infeksi kulit, demam berdarah sampai } \\
\text { hep atitis A, B, dan C. Penanganan limbah yang tidak baik juga } \\
\text { akan menimbulkan resiko terjadinya infeksi nosokomial. } \\
\text { Mewujudkan kualitas kesehatan lingkungan perlu ditetapkan } \\
\text { standar baku mutu kesehatan lingkungan dan persyaratan } \\
\text { kesehatan dengan melaksanakan pengamanan terhadap limbah } \\
\text { dan penyelenggaraan pengurangan limbah. Banyaknya fasilitas } \\
\text { kesehatan tersebut sudah menghasilkan limbah medis sebanyak } \\
\text { lebih dari } 296.86 \text { ton setiap harinya. Hanya sekitar } 43 \% \text { fasilitas } \\
\text { pelayanan kesehatan yang melaksanakan pengelolaan limbah }\end{array}$ \\
\hline
\end{tabular}




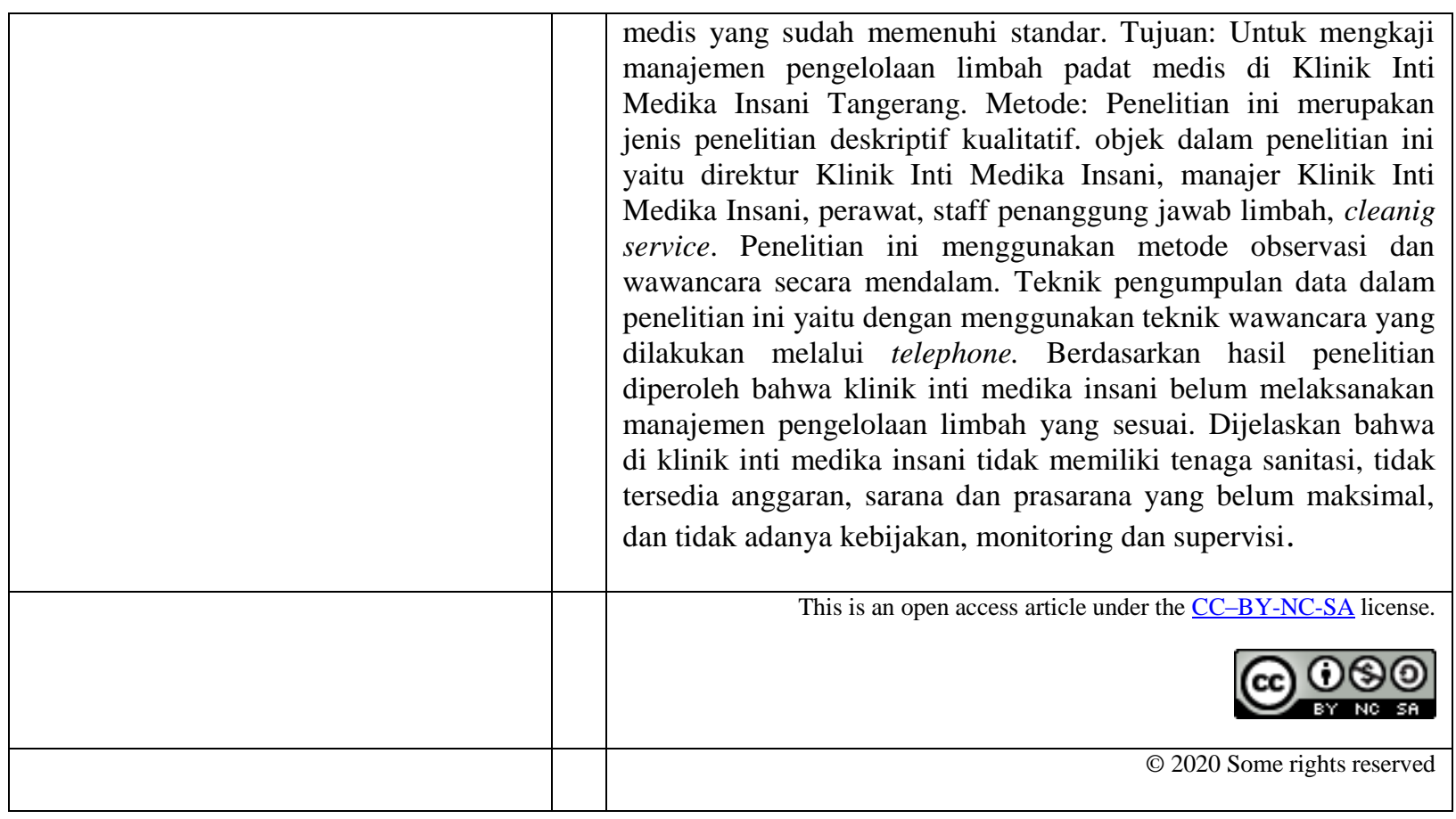




\section{PENDAHULUAN}

Berbagai macam dampak negatif timbul akibat adanya pengelolaan limbah yang tidak baik. Limbah medis membawa risiko yang lebih besar terhadap kesehatan, seperti diare, infeksi kulit, demam berdarah sampai hepatitis A, B, dan C. Penanganan limbah yang tidak baik juga akan menimbulkan risiko terjadinya infeksi nosokomial. Infeksi nosokomial (IN) adalah infeksi yang terjadi di rumah sakit atau disebabkan oleh kuman yang diperoleh selama berada di rumah sakit. Kasus infeksi nosokomial atau infeksi yang terjadi ketika pasien dirawat di rumah sakit di seluruh dunia rata-rata sembilan persen dari 1,4 juta pasien rawat inap (Purba and Khairunnisa, 2018).

Tahun 2019 terdapat sekitar 21.602 fasilitas pelayanan kesehatan, dimana 8.841 unit diantaranya adalah klinik pengobatan dan menghasilkan limbah medis lebih dari 296.86 ton setiap harinya. Hanya sekitar $43 \%$ fasilitas pelayanan kesehatan yang melaksanakan pengelolaan limbah medis yang sudah memenuhi standar (Fikria, 2020). Fasilitas pelayanan kesehatan wajib melakukan pengelolaan limbah B3. Pengelolaan tersebut yang meliputi pengurangan dan pemilahan limbah B3, penyimpanan limbah B3, pengangkutan limbah B3, pengolahan limbah B3, penguburan limbah B3, dan/atau penimbunan limbah B3. Upaya pengelolaan yang benar diperlukan investasi yang mahal dan biaya operasional yang tinggi, namun apabila tidak dikelola dengan benar selain dampaknya terhadap kesehatan dan lingkungan juga terancam dengan sanksi hukum dan denda yang tidak sedikit jumlahnya (Men LHK RI, 2015).

Penelitian yang dilakukan oleh Utami tahun 2017 yang berjudul "Analisis Pengelolaan Limbah Medis Padat pada Klinik/Praktek Dokter di Kota Makassar" dijelaskan bahwa sebagian klinik masih melakukan pengelolaan limbah padat medis dengan kurang baik seperti masih menyimpan limbah medisnya pada tempat yang kurang memenuhi syarat seperti di teras klinik, di halaman belakang, serta di dalam ruangan yang tidak diberi pendingin, kemudian mengangkut limbah medis secara manual, serta mengolah limbah medis dengan cara yang tidak tepat, seperti membuang pada tempat sampah domestik dan dibakar secara manual. Hal ini diakibatkan karena masih kurangnya perhatian dari pihak klinik terhadap penanganan limbah medis yang baik serta kurangnya pengawasan oleh instansi terkait. Berdasarkan hasil penelitian dapat diketahui bahwa pengelolaan limbah padat medis di Klinik/Praktek Dokter di 
Kota Makassar belum sesuai dengan peraturan.

Berdasarkan hasil studi pendahuluan diperoleh data bahwa Klinik Inti Medika Insani menerima pelayanan setiap harinya kurang lebih 200 pasien. Jumlah limbah yang dihasilkan dalam lima (5) bulan terakhir sebanyak $106 \mathrm{Kg}$. Klinik Inti Medika Insani sudah melakukan pewadahan limbah dengan sesuai seperti pewadahan limbah medis tajam pada box kuning. Pengolahan limbah dilakukan dengan bekerja sama pada pihak ketiga yang pengangkutannya dilakukan dalam waktu dua (2) bulan sekali namun dengan suhu Tempat Penampungan Sementara lebih dari $20^{\circ} \mathrm{C}$. hal ini bertolak belakang dengan Peraturan Menteri Lingkungan Hidup dan Kehutanan Nomor 56 Tahun 2015 dimana jika limbah disimpan lebih dari 2 hari maka suhu pada Tempat Penampungan Sementara (TPS) harus sebesar $0^{\circ} \mathrm{C}$, hal ini akan mengakibatkan bakteri dan virus berkembang biak lebih cepat dan munculnya berbagai macam penyakit yang diakibatkan dari bakteri dan virus tersebut.

Tujuan penelitian ini untuk mengkaji manajemen dari segi Sumber Daya Manusia (SDM), Standar Operasional Prosedur (SOP), anggaran, sarana prasarana, kebijakan, monitoring dan sepervisi pada pengelolaan limbah padat medis di Klinik Inti Medika Insani Tangerang tahun 2020 .

\section{METODE}

Jenis penelitian dalam penelitian ini adalah penelitian deskriptif dengan menggunakan pendekatan kualitatif. Penelitian ini dilaksanakan di Klinik Inti Medika Insani Tangerang yang beralamat di di Jl. Raya PLP Curug no 3A, Tangerang.selama empat (5) bulan, yakni pada Bulan Maret sampai Juli 2020. Sasaran dalam penelitian ini berjumlah lima (5) orang yang memiliki peran dan tanggung jawab masing-masing dalam pengelolaan limbah padat medis. Penentuan informan penelitian dalam penelitian ini menggunakan teknik triangulasi. Lima (5) informan tersebut terdiri dari satu (1) orang direktur Klinik Inti Medika Insani, satu (1) orang manajer Klinik Inti Medika Insani, satu (1) orang perawat, satu (1) orang penanggung jawab limbah, satu (1) orang cleaning service. Focus penelitian dalam penelitian ini antara lain: Sumber Daya Manusia (SDM), Standar Operasional Prosedur (SOP), Anggaran, Sarana dan Prasarana, Kebijakan, Monitoring, Supervisi. Data yang digunakan adalah data primer yang diperoleh langsung dari hasil wawancara dan observasi lapangan data sekunder informasi diperoleh dari data Klinik Inti Medika Insani Tangerang, sumber media 
internet, buku, dan penelitian terdahulu. Instrument dalam penelitian ini adalah wawancara mendalam dan observasi sedangkan teknik pengumpulan data yang dilakukan melalui via telephone dan pengisian lembar checklist. Data yang diperoleh disajikan dalam bentuk narasi dan dianalisis melalui tahapan: pengumpulan data, reduksi data, penyajian data, menarik kesimpulan.

\section{HASIL}

1. Pengelolaan limbah padat medis

a. Pengumpulan dan pemilahan.

Proses pengelolaan limbah padat medis di klinik Inti Medika Insani Tangerang melalui tahapan pengumpulan dan pemilahan.

"...ada dua tempat, tiga ama suntikan. Dua tempat sampah satu medis satu non medis yang satu lagi suntikan yang kardus gitu. Kalo yang kardus suntikan, aamm yaa suntikan aja, yang satunya handscone,yang satunya non medis" (CS02).

Limbah padat medis dilakukan pemilahan terlebih dahulu sebelum dilakukan pengangkutan ke tempat penampungan sementara guna untuk melihat apakah pewadahan limbah sudah sesuai dengan tempat masing-masing jenis limbah.

“... kalo sebelum pengangkutan yang kee itu yaa apasii, yang ke gudang, kalo disini si kalo yang semisal ada yang lupa masukin paling kita liat lagi aja, kalo misal ampul masuk ke kresek dimasukin sama aku ke box kaya gitu si mba. Iya sebelum ngangkut itu. Soalnya dari jalan hijaunya juga ngga bisa, harus sesuai pengelompokan ngga boleh di campur..." (PJ03).

b. Penyimpanan

Penyimpanan limbah padat medis sebelum diangkut ke tempat penampungan sementara tidak melebihi dari 1x 24 jam.

“...kalo limbah medis mah sehari biasanya sudah dibungkus yaa, kan ada plastik yang kuning. Kalo udah di bungkus langsung ditaro di gudang...." (PR01)

"...saya, saya hampir tiap hari si. Mau sift, sift malem tuh gitu, iya sift malem. Sehari sekali, pokoknya pagi diambil..." (CS02).

"...langsung diangkutin tiap hari, iyaa..." (PJ03).

Penyimpanan pada saat limbah dikumpulkan menggunakan wadah yang sesuai dengan ketentuan peraturan yang ditetapkan. Limbah medis menggunakan wadah 
berwarna kuning, sedangkan limbah medis dengan golongan tajam diwadahkan di tempat safety box. “...kalo yang limbah medis kan ada kantong khusus itu ya yang warna kuning ya untuk limbah infeksius itu. Kalo yang jarum di karton di safety box..." (PR01)

“...ee ada dua si kaya yang safety box buat jarum, suntikan,ampul, kalo semisal yang kresek kuning gitu buat sarung tangan, kasa steril, iya yang gitu gitu yaa..." (PJ03)

Penyimpanan limbah pada Tempat Penampungan Sementara (TPS) selama dua bulan sebelum limbah diangkut dan dilakukan tahap pengolahan.

“...kalo limbah medis kita kan pengangkutannya dua bulan sekali. Ke ininya kalo pengumpulannya kalo sudah penuh nanti kita kumpulin ada gudangnya sendiri eh emm..." (PR01).

“...kalau kita si di kumpulin dulu, jadi pengangkutanya kadang sebulan sekali...” (PJ03).

“...baru diangkut gitu kan, nah itu biasanya, biasanya dalam dua bulan sekali sudah ada yang ee apa namanya personil dari itu tadi ee pembuangan limbah itu..." (DR05)

c. Pengangkutan
Pengangkutan limbah medis dilakukan setiap hari tidak lebih dari 1 x 24 jam.

“...saya hampir tiap hari si. Mau sift, sift malem tuh gitu, iya sift malem. Sehari sekali, pokoknya pagi diambil...”(CS02).

“...langsung diangkutin tiap hari, iyaa..." (PJ03).

Pengangkutan ke TPS tidak menggunakan alat angkut khusus pengangkut limbah medis seperti troli atau sulo.

“...ngga ada si cuman di bungkus aja pake plastik kuningnya, ngga ada trolinya mba heheh. iya hehe Cuma diiket terus diangkut..." (PR01).

“...itu kan udah di plastik kuning langsung diambil. Nenteng doang di iket iya gituu..."(CS02).

“...karena kita ngga punya troli, paling kita angkutin satu-satu soalnya diatas, dipojok..." (PJ03). “emm ngangkut sampahnya, troli engga si, langsung aja di masukin kerdus gitu, jadi da pake. Diangkut aja..." (MN04)

Pengangkutan limbah padat medis melalui jalur khusus, tidak melewati jalur umum yang dilewati oleh pasien atau staff lain. 
“...Engga engga, kalau itu lewat jalan belakang. Jadi tidak lewat jalan..." (CS02).

“...kita ada lewat ada jalan lewat belakang gitu loh mba, ngga lewat kursi pasien gitu..." (PJ03).

d. Pengolahan

Klinik Inti Medika Insani Tagerang melaksanakan pengolahan limbah medis padat dengan cara bekerja sama dengan pihak ketiga. “...itu ama PT. PT jalan hijau kalau ngga salah..." (CS02). “...karena memang diwajibkan kan dari pemerintah, kemaren emang ada aturan surat edran kalau kita tuh eeee kita harus bekerja sama dengan ini emmm apah limbah swasta. akhirnya kita dapet PT jalan hijau" (MN04).

“...Nah itu kita suda ada kontrak dengan PT Jalan Hijau udah lama tuh yaa..." (DR05).

e. Penguburan dan Penimbunan

Klinik Inti Medika Insani Tangerang tidak pernah malakukan pengolahan limbah padat medis dengan cara di kubur atau di timbun.

“..."...kayaknya engga sih mba, paling kalo limbah obat-obatan yang expired gitu paling kita kubur itu juga ga terlalu banyak..." (PJ03). “...alhamdulillah kita belum pernah ada obat yang kadaluarsa ya karena kita belinya juga paling ee untuk tiga bulan gituu jadi cepet abis..." (MN04).

“...ngga pernah saya, ngga pernah ditimbun. Ngga pernah..." (CS02).

2. Sumber Daya Manusia (SDM)

Petugas yang bertanggung jawab menangani limbah di Klinik Inti Medika Insani Tangerang berpendidikan sebagai ahli Farmasi dan tidak pernah mengikuti pendidikan dan pelatihan mengenai tatacata pengelolaan limbah padat medis pada pelayanan kesehatan.

“...Engga, engga tau hehe. Saya operan dari medis sebelumnya kalau ini..." (PJ03).

“...sampai selama ini si saya ngga tau yaa kalau di klinik itu memang harus ada tenaga itu yaa, kalau memang harus ada ya...” (MN04)

“...belum sih, belum tau juga ada pelatihan kaya gitu. Ngga ada informasi..." (MN04).

“...kita cukup dengan panduanpanduan yang dari dinas kesehatan ketika mereka dateng awal itu segala macem kan mereka itu juga sudah memeberikan masukan ya, nah itu yang kemudian kita 
sosialisasikan, kita sampein kepada penanggung jawabnya..." (DR05).

3. Standar Operasioal Prosedur (SOP)

Secara administrasi, klinik inti medika insani tangerang sudah memiliki standar operasional prosedur penanganan limbah medis. "...kemaren udah di buat, cuman saya kurang paham juga hehehe udah di buat si, karena kita kan mau akreditasi, udah dibuat SOP penanganan limbah medis intinya si kaya gitu harus kerja sama, samaa pihak ketiga gitu, terus ada tempat penampungan sementara, gitu intinya si, eeehhh udah si itu aja sih yang saya tau..." (MN04).

Pengelolaan limbah medis berbahaya dalam prosesnya harus menerapkan standar operasional prosedur, seperti menggunakan alat pelinfung diri (APD). “...pake, pake sarung tangan, iya selain sarung tangan pake masker, kalo sepatu ngga pake sepatu, pake sepatu biasa aja...” (CSO2). “...Paling ya pake yang helm gitu, sarung tangan, sepatu boot, masker udah..." (PJ03).

Klinik Inti Medika Insani Tangerang bekelrja sama dengan pihak ketiga dalam pengolahan limbah. “...kalau manifest ada, yang kaya kertas kemaren itu ya. Iya si setiap pengambilan ada gitu..” (MN04).

Klinik inti medika insani belum mengerti regulasi atau peraturan mana yang digunakan sebagai pedoman dalam pengelolaan limbah padat medis dan hanya mengikuti panduan-panduan yang diarahlan oleh pihak atau dinas terkait.

“...regulasi kaya apa ya mba..emmm kurang tau ya mba, soalnya kan saya pegang ini baru satu tahunan...” (PJ03).

“...ketentuannya si saya ngga tau yaa yang penting saya si ini aja kalau ada jarum masukin ke yang box kuning ya... ketentuannya ngga tau deh seperti apa..." (MN04).

"...kalau peraturan hehe kurang tau nih hehe kalau peraturan yang terakhir, yang terakhir eeh sampe kapan kurang tau..." (DR05).

4. Anggaran

Klinik inti medika insani tangerang belum menyediakan anggaran secara khusus untuk pengadaan sarana prasarana pengelolaan limbah padat medis.

“...Kalau buat apd dan apa namanya kaya sarung tangan, masker, wadah buat sampahnya ada anggaran,, eee tapi ya aitu 
kalau abis,, alat abis baru dibeli..." (DR05).

“...Sebenernya kalau untuk disiapkan khusus sih engga juga, Cuma kalau abis aja anak-anak pada lapor 'abis ini plastik' baru kita beli gitu. APD juga kalau abis baru kita beli. Jadi ngga di iniin khusus si gitu...” (MN04). “...buat pengolahan itu saya gatau hehe. Mungkin ada emm kalau itu mungkin doret yang tau dee..." (PR01).

5. Sarana dan Prasarana

Klinik Inti Medika Insani memiliki sarana pengelolaan limbah seperti tempat pewadahan limbah padat medis, Alat Pelindung Diri (APD), Tempat Penampungan Sementara (TPS) serta jalan khusus yang digunakan untuk mengangkut limbah padat medis.

“...kalau apa APD udah, kan pasti pakai sarung tangan lah waktu itu yaa apalagi sekarang kalau udah dengan covid ini kan jauh lebih ketat, gitu yaa..." (DR05).

“...kita ada lewat ada jalan lewat belakang gitu loh mba, ngga lewat kursi pasien gitu..." (PJ03).

“...iya itu kita khususin untuk limbah padat disini dlam satu ruangan...”. “...ukuran gudang disini ya 3 meter x 1,5 meter..." (PJ03). "...gudangnya ada di dalem klinik. Dia ada di belakang, diatas..." (PR01).

“...pake, pake sarung tangan, iya selain sarung tangan pake masker, kalo sepatu ngga pake sepatu..." (CS02).

Lokasi tempat penampungan sementara (TPS) tidak berada di area umum.

“...Gudangnya ada di dalem klinik.

Dia ada di belakang, diatas., jauh. (PR01).

“...Ada di klinik. He'emh. Ya ruangan aja sih, ruangan buat sementara aja" (MN04).

“..oh itu, itu gudangnya ada di belakang sekali ngga boleh ada pasien dan di belakang sekali. Waah jauh jauh, jauh dari area umum wah ngga itu udah paling pojok dia posisinya" (CS02).

Tempat penampungan sementara (TPS) di Klinik Inti Medika Insani Tangerang belum memenuhi kriteria suhu yang telah ditetapkan oleh peraturan yang berlaku.

“...kayanya belum, belum dikasih atur suhu deh disitu. Iya belum. Kayanya kemaren ngga kena itu deh. Tapi gatau soalnya teh kokom yang ngurusin itu mah yang Pjnya" (PR01). 
“...Hehe nggapake apa-apa si. Ngga pake ac. Panas si ngga cuman ya gitu aja diatas di lantai dua"(CS02). “...berapa yaa. 22,8 sampai 25 kali ya mbaa" pokoknya kelembapanya 70\%...'(PJ03)

“...ini ngga ada ini sih, ngga ada apa namanya yaa eee omongan untuk itu, karena kita diambil rutin gitu ya..." (DR05).

Klinik Inti Medika Insani Tangerang tidak menyediakan atau tidak memiliki troli atau sulo sebagai wadah limbah saat dilakukan pengangkutan. “...Engga mba, itu kan udah di plastik kuning langsung diambil. Nenteng doang di iket iya gituu..." (CS02)

“...emm ngangkut sampahnya, troli engga si, langsung aja di masukin kerdus gitu, jadi da pake. Diangkut aja sama pak Agus ..."(MN04)

6. Kebijakan, Monitoring, Supervisi

Klinik inti medika insani tidak mempunyai kebijakan Hal ini dijelaskan melalui kutipan berikut ini melalui kutipan dari informan tambahan, informan kunci, dan informan utama.

“... ooh ngga ada mba, insyaallah ngikutin ketentuan yang udah ada..." (MN04).
“...Kalau kebijakan kita sudah mengikuti regulasi dan masukanmasukan..." (DR05)

“... kalau kebijakan tidak ada mba, iуaа.." (PJ03).

“... kayanya belum ada deh..." (PR01).

Klinik Inti Medika Insani tidak melaksanakan pengawasan/monitoring dan supervisi baik dari penanggungjawab klinik ataupun dari dinas terkait.

“...Kalau pengawasan langsung tidak ada mba, paling yaa kalau mau memperpanjang ijin klinik baru ditanya MOU..." “... selama ini si belum ada mba kalau monitoring, Eee dinas lingkungan yaa, itu juga barubaru aja si. Disuruh laporan gitu..." (MN04).

“.. supervisi juga ga ada mba..." (MN04)

“... belum pernah, setau saya yaa, belum pernah deh mba...” (PJ03).

“... kalau pengawasan si sampai saat ini ngga pernah sih mba...”. “...emmm pengawasan yaa, kalau selama kurang lebih satu tahun ini si ngga pernah ya teh.." (PJ03)

“...emmm kalau ituu juga kayanya engga ada deh mba" (PR01).

“...dokter Retno kan disini biasa ada rutin meeting ya apa dengan 
staff sehingga setiap penanggung jawab yang berhubungan dengan masukan-masukan tadi itu yaa

\section{PEMBAHASAN}

1. Pengelolaan limbah padat medis Pengelolaan limbah padat medis di klinik Inti Medika Insani Tangerang sebagian besar sudah melakukan pengelolaan limbah medis pada fasilitas pelayanan kesehatan sesuai dengan Peraturan Menteri Ligkungan Hidup dan Kehutanan Nomor 56 Tahun 2015. Pada pemberian simbol dan keterangan jenis limbah harus lebih dimaksimalkan pada setiap ruanganan pelayanan untuk menghindari adanya kesalahan dalam pengumpulan dan pemilahan. Penyimpanan limbah masih belum memenuhi kriteria peraturan Menteri Lingkungan Hidup dan Kehutanan Nomor 56 Tahun 2015 karena suhu dalam tempat penampungan sementara masih menggunakan suhu ruang saja dan tanpa bantuan pendiangi ruangan/ air conditioner $(A C)$ sedangkan limbah harus disimpan dalam suhu temperatur $3^{\circ} \mathrm{C}$ sampai dengan $8^{\circ} \mathrm{C}$ atau sembilan puluh (90) hari pada $0^{\circ} \mathrm{C}$. Pengangkutan limbah belum menggunakan alat angkut yang sesuai dengan peraturan. disampaikan 'iniloh ada tambahan misalnya begini..." (DR05).

2. Sumber Daya Manusia (SDM)

Perihal Sumber Daya Manusia (SDM) pada pengelolaan limbah padat medis ini, Klinik Inti Medika Insani Tangerang belum memenuhi standar persyaratan yang diharuskan. Berdasarkan Peraturan Menteri Lingkungan Hidup dan Kehutanan Nomor 56 Tahun 2015 pasal 32 menyatakan syarat tenaga yang bertanggung jawab menangani limbah ayat satu (1) adalah tenaga harus pernah mengikuti pendidikan dan pelatihan tentang pengelolaan limbah dan ayat dua (2) tenaga harus memiliki pengalaman di bidang pengelolaan limbah padat medis di fasilitas pelayanan kesehatan.

3. Standar Operasioal Prosedur (SOP) Pengelolaan limbah padat medis di Klinik Inti Medika Insani Tangerang sudah melaksanakan standar operasional prosedur (SOP) yang sesuai dengan ketentuan dan peraturan yang berlaku. Standar Opeasional Prosedur (SOP) tersebut meliputi pemakaian alat pelindung diri (APD), penggunaan wadahwadah limbah yang sesuai dengan ketentuan, penyediaan tempat 
penampungan sementara. Pengolahan

limbah yang dilakukan secara eksternal yakni bekerja sama dengan pihak ketiga, klinik Inti Medika Insani sudah memiliki perjanjian kerja dengan PT Jalan Hijau, dimana setiap kali dilakukan pengangkutan atau pengambilan limbah diberikan bukti manifest dari PT Jalan Hijau kepada Klinik Inti Medika Insani Tangerang.

Pengelolaan limbah padat medis di Klinik Inti Medika Insani Tangerang dalam prakteknya sudah dilakukan melalui perijinan dan mengikuti ketentuan-ketentuan yang diarahkan dari dinas-dinas terkait seperti Dinas Lingkungan Hidup dan Kehutanan (DLHK). Ketentuan-ketentuan sudah merujuk kepada peraturan pengelolaan limbah padat medis di fasilitas pelayanan kesehatan yakni Peraturan Menteri Lingkungan Hidup dan Kehutanan Nomor 56 Tahun 2015 .

\section{Anggaran}

Klinik Inti Medika Insani Tangerang tidak menyediakan dan tidak mengalokasikan anggaran khusus untuk pengelolaan limbah padat medis. Klinik Inti Medika Insani (IMI) Tangerang masih belum memasukan aspek anggraan dalam manajemen pengelolaan limbah padat medis pada fasilitas pelayanan kesehatan.

5. Sarana dan Prasarana

Pengelolaan limbah padat medis di Klinik Inti Medika Insani pada aspek penyediaan sarana dan prasarana untuk pengelolaan limbah padat medis masih belum maksimal. Hal ini dibuktikan dengan tidak adalanya alat angkut khusus limbha, tidak sesuainya suhu pada tempat penampungan sementara (TPS).

6. Kebijakan, Monitoring, Supervisi

Klinik Inti Medika Insani Tangerang tidak memiliki kebijakan terkait pengelolaan limbah padat medis. Klinik Inti Medika Insani Tangerang juga tidak melakukan pengawasan dan supervisi.

Tidak adanya kebijakan dalam pengelolaan limbah padat medis di fasilitas pelayanan kesehatan akan sangat berpengaruh pada proses pengelolaan limbah. Begitu juga dengan tidak adanya pengawasan dan supervisi yang dilakukan baik oleh penanggung jawab klinik maupun oleh badan dan dinas terkait. Hal ini akan berpengaruh pada ketidaksesuain pelaksanaan dengan syarat dan ketentuan yang diberlakukan dan akan sangat berpotensi menimbulkan dampakdampak negatif yang merugikan. 


\section{KESIMPULAN}

1. Pengelolaan limbah padat medis di Klinik Inti Medika Insani (IMI) Tangerang sudah melaksanakan pengelolaan sesuai dengan ketentuan peraturan berupa masukan-masukan yang diperoleh. Namun pada pelaksanaanya masih terdapat beberapa prinsip pengelolaan yang belum maksimal.

2. Dalam pengelolaan limbah padat medis di Klinik Inti Medika Insani Tangerang tidak mempekerjakan tenaga ahli bidang kesehatan lingkungan atau sanitasi. Tenaga yang bertangggung jawab juga tidak mempunyai sertifikasi di bidang pengelolaan limbah padat medis di fasilitas pelayanan kesehatan.

3. Klinik Inti Medika Insani sudah melaksanakan Standar Operasiona Prosedur (SOP) dalam pengelolaan limbah padat medis di fasilitas pelayanan kesehatan. Standar operasional terebut adalah dengan penyediaan sarana prasarana pengelolaan limbah padat medis, administrasi yang dilaksanakan dengan pihak yang terkait serta pengelolaan limbah yang sesuai dengan ketentuan atau peraturan yang berlaku.
4. Klinik Inti Medika Insani Tangerang tidak menyediakan anggaran khusus yang disediakan dalam periode waktu tertentu. Klinik Inti Medika Insani Tangerang juga tidak mengalokasikan secara khusus anggaran guna melakukan pengadaan sarana dan prasarana yang digunakan dalam pengelolaan limbah padat medis di fasilitas pelayanan kesehatan.

5. Klinik Inti Medika Insani Tangerang menyediakan sarana prasarana yang dibutuhkan dalam pengelolaan limbah padat medis di fasilitas pelayanan kesehatan seperti penyediaan alat pelindung diri (APD), wadah atau bak pengumpul limbah, jalur khusus pengangkutan limbah dan penyediaan tempat penampungan sementara limbah. Akan tetapi masih ada beberapa sarana yang belum maksimal karena belum memenuhi standar ketentuan yang diberlakukan.

6. Klinik Inti Medika Insani Tangerang tidak memiliki kebijakan terkait pengelolaan limbah padat medis. Klinik Inti Medika Insani Tangerang juga tidak melakukan pengawasan dan supervisi.

\section{DAFTAR PUSTAKA}

Adisasmito, Wiku. 2014. System manajemen lingkungan rumah sakit. Jakarta: Rajagrafindo Pers. 
Fikria. 2020. Keberadaan Limbah Medis. https://persmaporos.com/keberadaa n-limbahmedis/19/persmaporos/riset/

Idawati, Desi. Medyawati, H. 2011. Evaluasi Sistem Manajemen Pengelolaan Limbah Rumah Sakit (Studi Kasus Pada Rsup Persahabatan). Proceeding PESAT. ISSN: 1858-2559.

Klinik Inti Medika Insani Tangerang, 2020.

Keputusan Menteri kesehatan Republik Indonesia tentang Persyaratan Kesehatan Lingkungan Nomor 1204 Tahun 2014

Notoatmodjo.S.2010.Metodologi Penelitian Kesehatan.Raja Grafindo. Jakarta

Oktavianty, H. P. 2016.'Analisis Sistem Manajemen Lingkungan Rumah Sakit dalam Aspek Pengelolaan Limbah Medis Padat ( Studi Kasus Rumah Sakit Umum Daerah Kardinah Kota Tegal )'.

Peraturan Menteri Lingkungan Hidup dan Kehutanan Nomor 56 tentang Tata Cara dan Persyaratan Teknis Pengelolaan Limbah di Fasilitas Pelayanan Kesehatan. Tahun 2015.

Peraturan Menteri Kesehatan Republik Indonesia Nomor 27 tentang Pedoman Pencegahan dan Pengendalian Infeksi di Fasilitas Pelayanan Kesehatan. Tahun 2017.

Perdanawati Pitoyo, P. N., Arthana, I. W. and Sudarma, I. M. 2016.'Kinerja Pengelolaan Limbah Hotel Peserta Proper Dan Non Proper Di Kabupaten Badung, Provinsi Bali'.ECOTROPHIC : Jurnal Ilmu
Lingkungan (Journal of Environmental Science), 10(1), p. 33. doi: 10.24843/ejes.2016.v10.i01.p06.

Purba, E. S. and Khairunnisa, C. 2018.'Hubungan Pengetahuan, Sikap Dan Ketersediaan Fasilitas Dengan Praktik Petugas Pengumpul Limbah Medis Di Rumah Sakit Umum Cut Meutia Kabupaten Aceh Utara Tahun 2015'.AVERROUS: Jurnal Kedokteran dan Kesehatan Malikussaleh, 1(2), p. 23. doi: 10.29103/averrous.v1i2.401.

Putri, D. A. P. G. M. S., Pertiwi, N. K. F. R. and Nopiyani, N. M. S. 2018.'Manajemen Pengelolaan Limbah Medis di Praktik Dokter Gigi Kabupaten Tabanan', Bali Dental Journal, 2(1), pp. 9-16. Available at: http://jkgudayana.org/ojs/index.php/bdj/articl e/view/18.

Rachmawati, Siti. dkk. 2018. Analisis Manajemen Pengelolaan Limbah Padat Medis B3 Di Rumah Sakit Universitas Sebelas Maret Surakarta. Prosiding SNST ke-9 Tahun 2018, ISBN 978602-99334-99.-

Randa. Irzan Yusfa.2016. Hubungan Perilaku Petugas Dengan Penangananlimbah Medisdi Rsud Haji Kota Makassar Tahun 2016. Skripsi

Sugiyono, 2016.Metode Penelitian Kuantitatif, Kualitatif dan $R \& D$.Bandung:PT. Alfabet.

Undang-undang Republik Indonesia Nomor 18 tentang Pengelolaan Sampah.Tahun 2008 
Undang-undang Republik Indonesia Nomor 36 tentang Kesehatan.

Tahun 2009

Utami.Nadia.2017. Analisis Pengelolaan Limbah Medis Padat Pada Klinik/Praktek Dokter Di Kota Makassar.Skripsi

Yulian. Risty. 2016. Evaluasi Sistem Pengelolaan Limbah Padat Medis Dan Non Medis RS DR. Soedirman Kebumen. Skripsi.

Yulinto, B., Kursani.E., dan Indra, R. A. 2017 'Manajemen Pengelolaan Limbah Medis Padat Di Rumah Sakit Umum Daerah Kota Dumai', Jurnal Bahan Kesehatan Masyarakat, 1(2), pp. 96-105. Available at: http://journal.poltekkesjambi.ac.id/i ndex.php/JBKM/article/view/3. 